ROCZNIKI NAUK PRAWNYCH

Tom XXXI, numer 3 - 2021, s. 57-75

DOI: http://doi.org/10.18290/rnp21313.4

\author{
MONIKA MÜNNICH \\ Katolicki Uniwersytet Lubelski Jana Pawła II \\ mmunnich@kul.pl \\ ORCID: https://orcid.org/0000-0001-5305-8239 \\ GRZEGORZ MATYSEK \\ Uniwersytet Marii Curie-Skłodowskiej w Lublinie \\ grzegorz.matysek@umcs.lublin.pl \\ ORCID: https://orcid.org/0000-0001-5305-8239
}

\title{
WĘZŁOWE PROBLEMY DOTYCZĄCE PRAW PODMIOTOWYCH PODATNIKÓW
}

\author{
KEY PROBLEMS REGARDING THE SUBJECTIVE RIGHTS OF TAXPAYERS
}

\begin{abstract}
Representatives of the Polish tax doctrine generally focus in their deliberations on the general rights of the taxpayer and their protection, while the issue of public subjective rights of the taxpayer is not discussed at all. This article addresses the gap, which aim is, firstly a theoretical analysis of the concept of subjective law. Secondly, an attempt to systematize taxpayers' subjective rights regulated in various legal acts. Thirdly, showing on the basis of the exemplification of selected subjective rights regulated in the corporate income tax, their potential importance as instruments securing the rights of the taxpayer and the basis for shaping new relations between them and tax authorities based on partnership and equality.
\end{abstract}

Keywords: subjective law; rights of the taxpayer; corporate income tax; tax authorities

\section{WPROWADZENIE}

Problematyka praw podmiotowych podatnika jest w literaturze przedmiotu rzadko podejmowana. $\mathrm{Z}$ reguły przedstawiciele polskiej doktryny podatkowej koncentrują się na ogólnych katalogach praw podatnika oraz ich ochronie w prawie podatkowym krajowym ${ }^{1}$ lub unijnym ${ }^{2}$. Niestety, dotych-

\footnotetext{
${ }^{1} \mathrm{~Np}$. B. SzCZUREK, Koncepcja ochrony praw podatnika. Geneza, rozwój, perspektywy, Warszawa: C.H. Beck 2008; B. BRZEZIŃSKI, Koncepcja praw podatnika i ich ochrony jako przedmiot
} 
czas żadna $\mathrm{z}$ inicjatyw związanych czy to $\mathrm{z}$ upowszechnieniem praw podatnika $\mathrm{w}$ formie niewiążącej deklaracji praw podatnika ${ }^{3}$, czy też $\mathrm{w}$ formie odrębnego aktu prawnego, np. Karty Praw Podatnika ${ }^{4}$, bądź w ramach szerszego aktu prawnego, np. nowej wersji ordynacji podatkowej ${ }^{5}$, nie doczekały się skutecznej realizacji.

Wobec braku przyjęcia deklaratywnych lub formalnoprawnych rozwiązań zawierających enumeratywny lub przykładowy katalog praw podatnika, zasadne wydaje się przeanalizowanie obowiązujących przepisów prawa podatkowego pod kątem wyinterpretowania $\mathrm{z}$ nich praw podmiotowych podatnika, rozumianych jako instrumenty wzmacniające i zabezpieczające pozycję podatnika $\mathrm{w}$ relacjach $\mathrm{z}$ organami podatkowymi ${ }^{6}$.

badań naukowych, „Kwartalnik Prawa Podatkowego” 2005, nr 1, s. 9-34. H. DzwonkowsKI, M. DuDA, J. GoRĄCA, Zakres i treść istniejącej i pożądanej ochrony praw podatnika (ustalenia de lege lata i postulaty de lege ferenda), http://orka.sejm.gov.pl/wydbas.nsf/0/A045899E99633E82C1257F B200456DB9/\$File/Strony\%20odDylematy\%20reformy\%20systemu\%20podatkowego-12.pdf [dostęp: 8.07.2020].

2 J. KISZKA, Zasady ochrony podatnika w orzecznictwie Europejskiego Trybunatu Sprawiedliwości, „Gdańskie Studia Prawnicze” 16 (2007), nr 1, s. 455-483; B. BrzezIŃSKI, A. FrANCZAK, Wymiana informacji podatkowych a ochrona praw podstawowych $w$ sferze opodatkowania - wyrok TSUE w sprawie Berlioz (C-682/15). Glosa, „Problemy Współczesnego Prawa Międzynarodowego, Europejskiego i Porównawczego" 17 (2019), s. 269-278; A. FrANCZAK, Standardy ochrony praw podatnika w Karcie Praw Podstawowych i ich stosowanie w orzecznictwie sadów administracyjnych, „Roczniki Nauk Prawnych” 30 (2020), nr 1, s. 33-48.

${ }^{3}$ B. BrZEZIŃSKI, Deklaracja Praw Podatnika (propozycja systematyzacji tez), „Kwartalnik Prawa Podatkowego" 2008, nr 2, s. 111-121. M. MüNnICH, Deklaracja Praw Podatnika, [w:] Preferencje podatkowe, red. B. Kucia-Guściora, M. Burzec, Lublin: Wydawnictwo KUL 2013, s. 13-28.

${ }^{4}$ M. SĘK, Karta Praw Podatnika $w$ polskim systemie podatkowym $w$ świetle doświadczeń zagranicznych, „Kwartalnik Prawa Podatkowego” 2018, nr 1, s. 71-96. M. WILK, Potrzeba wprowadzenia Karty Praw Podatnika w Polsce, „Kwartalnik Prawa Podatkowego” 2018, nr 1, s. 97-104; Projekt ustawy Karta Praw Podatnika z uzasadnieniem w: „Kwartalnik Prawa Podatkowego” 2018, nr 1, s. 105-127; Karta Praw Podatnika - nowym instrumentem ochrony dla podatników, https:// www.rpo.gov.pl/pl/content/rpo-za-wprowadzeniem-karty-praw-podatnika [dostęp: 5.02.2021]. Istnieje również projekt przygotowany przez Ministerstwo Finansów ustawy dnia.... 2019 r. Karta Praw Podatnika opracowany przez Ministerstwo Finansów, http://orka.sejm.gov.pl/Druki8ka.nsf/Projekty/ 8-020-1306-2019/\$file/8-020-1306-2019.pdf [dostęp: 5.02.2021].

${ }^{5}$ Zob. rządowy projekt ustawy - Ordynacja podatkowa, druk nr 3718 https://www.sejm.gov.pl /sejm8.nsf/druk.xsp?nr=3517 [dostęp: 15.09.2021]. Omówienie proponowanych w projekcie ogólnych praw podatnika zob. L. Etel, S. BABIARZ, R. Dowgier [i in.], Nowa Ordynacja Podatkowa. Z prac Komisji Kodyfikacyjnej Ogólnego Prawa Podatkowego, Białystok: Temida 2 2017, s. 100-105.

${ }^{6} \mathrm{~W}$ piśmiennictwie zwrócono już uwagę, że do opisu wzajemnych relacji między podatnikiem a organem podatkowym można odnieść tytułową koncepcję publicznych praw podmiotowych, zob. A. NAPIÓRKowsKA, Czy ktoś chroni podatnika?, [w:] Podatnik versus organ podatkowy, red. P. Borszowski, A. Huchla, E. Rutkowska-Tomaszewska, s. 146-147, https://www.biblioteka cyfrowa.pl/dlibra/publication/37394/edition/38915/content [dostęp: 5.07.2021]; H. DzwonkowSKI, M. DuDA, J. GORĄCA, Zakres i treść istniejącej i pożądanej ochrony praw. 
Celem niniejszej publikacji jest, po pierwsze, teoretyczna analiza pojęcia prawa podmiotowego transponowanego z prawa prywatnego do prawa podatkowego. Po wtóre, próba usystematyzowania unormowanych w różnych aktach prawnych przysługujących podatnikom praw podmiotowych. Po trzecie, ukazanie na podstawie egzemplifikacji wybranych praw podmiotowych unormowanych w podatku dochodowym od osób prawnych ich potencjalnego znaczenia jako instrumentów zabezpieczających prawa podatnika i podstawę do kształtowania nowych relacji pomiędzy nimi a organami podatkowymi opartych na partnerstwie i równorzędności.

\section{POJĘCIE PUBLICZNEGO PRAWA PODMIOTOWEGO W ŚWIETLE JUDYKATURY I PIŚMIENNICTWA}

Zdaniem przedstawicieli jurysprudencji prawo podmiotowe jest pochodną sytuacji prawnej jakiegoś podmiotu wyznaczoną mu przez normy prawne danego systemu prawnego. Zwrot „ma prawo” może oznaczać przymiot posiadania tzw. wolności dwustronnej, czyli sytuację, gdy dany podmiot jest jednocześnie uprawniony i jego wolność jest prawnie chroniona, a także przysługuje mu też określona kompetencja w postaci np. roszczenia ${ }^{7}$.

Prawo podmiotowe, pomimo że historycznie związane z prawem cywilnym, nie jest już jego wyłączną domeną, gdyż ta kategoria prawna funkcjonuje także w prawie publicznym, w tym również w prawie podatkowym. Doktryna administracyjno-prawna postrzega prawo podmiotowe jako taką sytuację jednostki, w której posiada ona opartą na normie prawnej możność żądania (roszczenia) konkretnego zachowania wobec jednostki organu reprezentującego podmiot prawa publicznego ${ }^{8}$. Tak rozumiane pojęcie publicznego prawa podmiotowego łączy zatem interes prawny oraz roszczenie, co oznacza, że prawo to służy ochronie jednostki, a najlepszym tego wyrazem jest

\footnotetext{
${ }^{7}$ S. WronKowsKa, Sytuacje wyznaczone przez normy prawne, [w:] A. REDELBACH, S. WronKOWSKA, Z. ZIEMBIŃSKI, Zarys teorii państwa i prawa, Warszawa: PWN 1994, s. 62, 150-151; J. KACZOR, Nadużycie prawa podmiotowego, [w:] Z zagadnień teorii i filozofii prawa. Autonomia prawa ze stanowiska teorii i filozofii prawa, red. J. Helios, Wrocław: Wydawnictwo Uniwersytetu Wrocławskiego 2003, s. 114.

${ }^{8}$ Zob. S. KASZnICA, Polskie prawo administracyjne, Poznań: Księgarnia Akademicka 1946, s. 126; W. JAKIMOWICZ, Publiczne prawa podmiotowe, Kraków: Zakamycze 2002, s. 135; K. ToMASZEWSKA, Znaczenie i zakres ochrony publicznych praw podmiotowych a ochrona interesu jednostki, s. 113-134, http://www.bibliotekacyfrowa.pl/Content/39984/06_Katarzyna Tomaszewska.pdf [dostęp: 11.09.2020] oraz P. TulejA, Stosowanie Konstytucji RP w'świetle zasady jej nadrzędności (wybrane zagadnienia), Kraków: Wolters Kluwer 2003, s. 130-142.
} 
uprawnienie do wniesienia skargi sądowej ${ }^{9}$. Publiczne prawa podmiotowe nie dotyczą zatem relacji pomiędzy obywatelami, lecz pomiędzy obywatelami a organami publicznymi ${ }^{10}$. Jednakże celem ich wprowadzania do treści norm prawnych jest zabezpieczenie nie tylko interesu jednostkowego, ale także interesu publicznego. Z uwagi na tę ostatnią cechę podmiot wyposażony w publiczne prawo podmiotowe nie może się go zrzec, ale może z niego nie skorzystać ${ }^{11}$.

W orzecznictwie wskazuje się, że publiczne prawo podmiotowe jest wprawdzie ściśle związane z normą prawną i nie może istnieć „obok” lub „poza” nią, czy też ze stosunkiem prawnym ukształtowanym przez tę normę, ale nie można go jednak utożsamiać z samą normą prawa, czyli z prawem przedmiotowym. Publiczne prawo podmiotowe jest bowiem efektem interpretacji normy prawa ze względu na jednostkę. Źródłem publicznego prawa podmiotowego jest zatem zawsze norma prawna, jednakże nie każda norma prawna jest źródłem prawa podmiotowego, nawet wówczas, gdy tworzy ona pewne sytuacje korzystne dla jednostki ${ }^{12}$.

Podstawowy podział publicznych praw podmiotowych jest budowany na podstawie kryterium treści, według którego dzieli się je na:

a) negatywne prawa podmiotowe, które polegają na roszczeniu uprawnionych podmiotów (zwłaszcza jednostek) wobec władzy publicznej o zaniechanie ingerencji $\mathrm{w}$ sferę uznanej uprzednio wolności lub przyznanego stanu prawnego (np. roszczenie o nieingerowanie w przebieg legalnej demonstracji);

b) pozytywne prawa podmiotowe, które polegają na roszczeniu uprawnionych podmiotów wobec władzy, by przyznała przysługujące im świadczenia lub zapewniła korzystanie $\mathrm{z}$ uprawnień, w tym m.in. $\mathrm{z}$ uprawnień formalnoprawnych, politycznych ${ }^{13}$.

\footnotetext{
${ }^{9}$ Publiczne prawo podmiotowe jest też pojęciem, na podstawie którego zbudowane zostało sądownictwo administracyjne. Zob. wyrok WSA w Warszawie z 5 marca 2013, II SA/Wa 2334/12, Centralna Baza Orzecznictwa Sądów Administracyjnych; K. ToMASzEwSKA, Znaczenie i zakres ochrony publicznych praw, s. 117-118.

${ }^{10}$ Zob. Z. Duniewska, B. Jaworska-DęBSKa M. Stahl [i in.], Prawo administracyjne. Pojęcia, instytucje, zasady w teorii i orzecznictwie, Warszawa: Wolters Kluwer 2009, s. 75-77, 79.

${ }^{11}$ Zob. tamże, s. 77.

${ }^{12}$ Zob. wyrok WSA w Warszawie z 5 marca 2013, II SA/Wa 2334/12, Centralna Baza Orzecznictwa Sądów Administracyjnych. W świetle teorii prawa prawo podmiotowe zapewnia posiadającemu je podmiotowi możność swobodnego podejmowania decyzji co do swego zachowania, realizowania przedsięwziętych działań oraz domagania się od innych wykonania nałożonych na nich obowiązków, które są niezbędne do przeprowadzenia jego konkretnego uprawnienia, zob. T. CHAUVIN, T. STAWECKI, P. WinCZOREK, Wstęp do prawoznawstwa, Warszawa: C.H. Beck 2013, s. 94.

${ }^{13}$ Zob. wyrok WSA w Warszawie z 5 marca 2013, II SA/Wa 2334/12, Centralna Baza Orzecznictwa Sądów Administracyjnych.
} 
Bez wątpienia powyższy podział praw podmiotowych znajduje również swoje odzwierciedlenie w przepisach prawa podatkowego.

\section{SYSTEMATYKA PRAW PODMIOTOWYCH PODATNIKA}

Systematykę praw podmiotowych unormowanych w przepisach prawa podatkowego poprzedzić należy wyjaśnieniem, że w prawie podatkowym, tak samo jak w cywilnym, prawa podmiotowe mogą mieć charakter majątkowy lub niemajątkowy. Przy czym w przypadku prawa majątkowego nie ma znaczenia to, czy ma ono jakąś wartość rynkową, czy nie, gdyż np. prawo własności zawsze traktowane jest jako prawo majątkowe, choćby jego przedmiotem była rzecz bezwartościowa. Prawa majątkowe to takie uprawnienia podatnika, które kształtują jego interes ekonomiczny, wpływają na stopień obciążenia podatkiem bądź też powodują, że obciążenia podatkowego nie ma w ogóle $\mathrm{e}^{14}$. Prawa o charakterze niemajątkowym dotyczą obszaru praw osobistych i rodzinnych, odnoszących się np. do relacji między małżonkami czy krewnymi ${ }^{15}$.

W odniesieniu do prawa podatkowego wydaje się, że nie ma wątpliwości co do kwalifikowania jako praw podmiotowych oczywistych praw majątkowych podatnika unormowanych $\mathrm{w}$ konkretnych przepisach podatkowych ${ }^{16}$. Za prawa podmiotowe uznawane są takie prawa majątkowe, jak prawa rzeczowe (własność, użytkowanie wieczyste), obligacyjne (np. najmu, dzierżawy, renta umowna), prawa na dobrach niematerialnych o charakterze majątkowym (np. prawa autorskie), rodzinne o charakterze majątkowym (np. prawo do alimentów) czy prawa spadkowe ${ }^{17}$.

Jednakże z punktu widzenia niniejszych rozważań zdecydowanie bardziej interesujące są analizy dotyczące tego, czy za prawa podmiotowe można

${ }^{14}$ Tak m.in. wyrok WSA w Gliwicach z 20 listopada 2018 r., I SA/GL 653/18, LEX nr 2585928; wyrok WSA w Lublinie z 4 listopada 2015 r., I SA/Lu 651/15, LEX nr 1944604.

${ }^{15}$ Zob. wyrok WSA z 10 lutego 2005 r., III SA/Wa 1007/04, LEX nr 251241. Zob. także S. BABIARZ, Majątkowe i niemajątkowe prawa i obowiazki w systemie praw, cz. II. Majątkowe i niemajątkowe prawa i obowiąki w prawie podatkowym. Teza $n r 1$, „Zeszyty Naczelnego Sądu Administracyjnego" 2006, nr 2, s. 21.

${ }^{16}$ Zob. np. art. 7 b ust. 1 pkt 6 lit. a ustawy z dnia 15 lutego 1992 r. o podatku dochodowym od osób prawnych, tekst jedn.: Dz.U. z 2020 r., poz. 1406 [dalej: u.p.d.o.p.] oraz 17 i 18 ustawy z dnia 26 lipca 1991 r. o podatku dochodowym od osób fizycznych, tekst jedn.: Dz.U. z 2020 r., poz. 1426 ze zm. [dalej: u.p.d.o.f.]. W odniesieniu do p.d.o.f. zob. interpretacja indywidualna Dyrektora KIS z 23 listopada 2018 r., 0113 - KDIPT2-3-4011.526.2018.ID.

${ }^{17}$ Zob. wyrok WSA w Szczecinie z dnia 3 marca 2016 r. I SA/Sz 1408/15, LEX nr 2014108. 
uznać inne aniżeli wymienione wyżej instytucje prawnopodatkowe ważne z punktu widzenia ochrony praw podatnika? W celu udzielenia odpowiedzi na to pytanie niezbędne jest usystematyzowanie i wyjaśnienie, które rodzaje uprawnień przysługujących podatnikom można zaliczać do obszaru praw podmiotowych.

Za kluczowe w dalszych rozważaniach należy przyjąć następujące cechy identyfikujące uprawnienia podatnika, wskazujące na ich charakter jako publicznych praw podmiotowych. Po pierwsze, na etapie stosowania przepisów prawa podatkowego, w których unormowane jest prawo podmiotowe, organ nie może kierować się uznaniem administracyjnym i nie może w żaden sposób ograniczać podmiotowi uprawnionemu możliwości skorzystania z tego prawa. Po drugie, podmiot wyposażony w publiczne prawo podmiotowe nie może się go zrzec, ale może z niego nie skorzystać. Po trzecie, organ nie może zmuszać podmiotu do wykorzystania przysługującego mu prawa, jeśli podmiot ten uczynić tego nie chce. Niespełnienie chociażby jednej z wyżej wskazanych cech publicznego prawa podmiotowego oznacza, że dana instytucja prawna nie jest publicznym prawem podmiotowym.

Ważąc powyższe teoretyczne przesłanki, można zaproponować następujący podział praw podmiotowych przysługujących podatnikom:

1) konstytucyjne prawa podmiotowe podatnika,

2) prawa podmiotowe podatnika sensu stricto,

3) prawa podmiotowe sensu largo, czyli takie, które wywodzone są z praw podstawowych.

Problematyka konstytucyjnych praw podmiotowych podatnika była już przedmiotem wielu orzeczeń $\mathrm{TK}^{18}$ oraz badań w piśmiennictwie ${ }^{19}$. Wydaje się, że w tym momencie, jako rozstrzygający kwestię możliwości powoływa-

${ }^{18}$ Stanowisko TK ewoluowało, znane są bowiem wyroki, w których TK jednoznacznie wskazywał na to, że z treści art. 84, a przede wszystkim art. 217 Konstytucji Rzeczypospolitej Polskiej z dnia 2 kwietnia 1997 r. (Dz.U. Nr 78, poz. 483) można wywieźć prawa podmiotowe podatników, zob. wyroki TK: z 4 listopada 1999 r., K 28/98, https://isap.sejm.gov.pl/isap.nsf/ download.xsp/WDU19990921062/T/D19991062L.pdf_[dostęp: 5.02.2021]; 27 grudnia 2004 r., SK 35 /02, Dz.U. z 2005 r., Nr 1, poz. 4 oraz 2 kwietnia 2007 r., SK 19/06, Dz.U. z 2007 r., Nr 69 poz. 468. Przeciwne stanowisko natomiast TK zajął w wyrokach z 5 listopada 2008 r., SK 79/06, OTK ZU (2008), nr 9, poz. 153 i z 12 kwietnia 2011 r., Sk 62/08, Dz.U. z 2011 r., Nr 87, poz. 492, oraz postanowieniu z 18 listopada 2008 r., SK 23/06. Stanowisko takie podzielił także Marszałek Sejmu RP w Piśmie do TK o sygn. SK 3/18, BAS-WAKiU-841/18 z 17 stycznia 2019 r.

${ }^{19}$ A. KrzYwoń, Podatki i inne daniny publiczne w Konstytucji Rzeczypospolitej Polskiej, Warszawa: Wydawnictwo Sejmowe 2011, s. 110-111; T. DĘBOwSKA-RoMANOwSKA, Dylematy interpretacyjne artykutu 217 Konstytucji, [w:] Ex iniuria non oritur ius. Ksiegga ku czci Profesora Wojciecha Łączkowskiego, red. A. Gomułowicz, J. Małecki, Poznań: Wydawnictwo Printer 2003, s. 213. 
nia się przez podatników na przysługujące im konstytucyjne prawa podmiotowe, przyjmowany jest pogląd, w myśl którego przepisy Konstytucji gwarantujące lub przyznające określone wolności i prawa, mogą być adekwatnym wzorcem kontroli także dla przepisów nakładających obowiązki, o ile zachodzi rzeczywisty związek pomiędzy realizacją danego obowiązku a ingerencją prawodawcy w sferę konkretnej wolności lub prawa jednostki proklamowanych przez Konstytucję $e^{20}$.

W piśmiennictwie podkreśla się, że przepisy Konstytucji RP normują nie tylko sposób nakładania podatków, ale stwarzają także dla uiszczających je podatników określone gwarancje ich praw i wolności ${ }^{21}$. Podatki i inne daniny publiczne ze swej istoty stanowią ingerencję w prawo własności i inne prawa majątkowe podatników, mogą one także ograniczać sferę wolności gospodarczej. Jednakże sama realizacja zasady powszechności opodatkowania nie oznacza w żadnej mierze naruszenia praw i wolności jednostki. O takim zjawisku można mówić dopiero wówczas, gdy nastąpi wykroczenie poza konstytucyjnie dopuszczalne granice czy to materialne, czy też proceduralne nakładania danin i innych ciężarów publicznych. Sumując, na mocy art. 84 i 217 Konstytucji podatnicy mają prawo oczekiwać, że sposób nakładania podatków będzie gwarantował im pewność, stałość i przewidywalność tak, aby zapłata podatku nie łączyła się z nadmiernym obciążeniem (konfiskatą mienia $)^{22}$ bądź też z niepewnością co do skutków już zapłaconych wcześniej należności, lub z pojawieniem się nowych podatków nieuwzględniających

\footnotetext{
${ }^{20}$ Postanowienie TK z dnia 16 lutego 2009 r., Ts 202/06, OTK ZU 2009, nr 1B, poz. 23; por. także postanowienie TK z 31 maja 2011 r., Ts 295/10, https://www.saos.org.pl/judgments/110787 [dostęp 7.07.2021]; postanowienie TK z 8 czerwca 2011 r., Ts 41/07, OTK-B 2011, nr 3, poz. 194; wyrok TK z 13 grudnia 2017 r., SK 48/15, Dz.U. z 2017 r., poz. 2432.

${ }^{21}$ Szerzej zob. T. Dęвowska-Romanowska, Dylematy interpretacyjne, s. 213. Por. także A. GomUŁowICZ, Ochrona wolności i praw ekonomicznych a granice opodatkowania - zasady $i$ kontrowersje, „Ruch Prawniczy, Ekonomiczny i Socjologiczny” 67 (2005), nr 3, s. 30.

${ }^{22} \mathrm{TK}$ wielokrotnie podkreślał, że przepisy regulujące problematykę danin publicznych muszą być zgodne z całokształtem obowiązujących norm i zasad konstytucyjnych, nie mogą prowadzić do naruszenia wartości objętych ochroną konstytucyjną, a w szczególności nie mogą kształtować obowiązku podatkowego $\mathrm{w}$ taki sposób, że stałby się on instrumentem konfiskaty mienia, zob. wyroki z: 7 czerwca 1999 r., K. 18/98, OTK ZU 1999, nr 5, poz. 95; 5 stycznia 1999 r., K. 27/98, OTK ZU 1999, nr 1, poz. 1; 25 listopada 1997 r., K. 26/97, OTK ZU 1997, nr 5-6, poz. 64. Podobnie zob. wyrok TK z 11 grudnia 2001 r. SK 16/00, Dz.U. z 2001 r., Nr 144, poz. 1621; postanowienie TK z 3 października 2003 r., Ts 108/03, OTK-B 2004, nr 4, poz. 239; wyrok TK z 25 października 2004 r., SK 33/03, Dz.U. z 2004 r., Nr 237, poz. 2382; wyrok TK z 30 listopada 2004 r., SK 31/04 OTK ZU 2004, nr 10A, poz. 110; wyrok z 5 listopada 2008 r., SK 79/06, OTK ZU 2008, nr 9A, poz. 153; wyrok TK z 17 listopada 2010 r., SK 23/07, OTK ZU 2010, nr 9A, poz. 103. Analiza podanych wyroków zob. A. KRZYwoŃ, Podatki i inne daniny, s. 110-111n.
} 
zastanych interesów w toku ${ }^{23}$. W doktrynie prawa podatkowego już od dawna konstytucyjne gwarancje, wynikające $\mathrm{z}$ powołanych wyżej artykułów Konstytucji RP, wiąże się z gwarancjami wynikającymi z przepisów, które dotyczą wolności i praw ekonomicznych ${ }^{24}$, prawa do prywatności ${ }^{25}$, zasady równości ${ }^{26}$, zasady demokratycznego państwa prawnego ${ }^{27}$ oraz zasady działania organów władzy publicznej na podstawie i w granicach prawa ${ }^{28}$.

Drugi rodzaj praw podmiotowych podatników, czyli prawa podmiotowe sensu stricto, unormowany jest w zwykłych ustawach podatkowych. Prawa podmiotowe sensu stricto, inaczej mówiąc: „właściwe”, to takie, które mają charakter bezwzględnie obowiązujących, bezwarunkowych (nieuzależnianych od uznania administracyjnego), a o ich zastosowaniu w konkretnych sprawach podatkowych decyduje samodzielnie podmiot, któremu one przysługują. Jako przykłady tego typu praw podmiotowych przysługujących podatnikom, najczęściej w literaturze i judykaturze wskazuje się prawo do zwrotu podatku naliczonego $\mathrm{VAT}^{29}$ czy też prawo do nadpłaty ${ }^{30}$. W przepisach prawa podatkowego znajduje się jednak znacznie więcej praw podmiotowych. Egzemplifikacji tych praw poświęcony jest kolejny punkt artykułu.

Natomiast trzecia kategoria praw podmiotowych podatnika, czyli sensu largo, to takie prawa, które pomimo niespełniania cechy bezwarunkowości, a więc mimo pewnego uzależnienia ich zastosowania od uznania administracyjnego organu dokonującego wiążącej wykładni operatywnej, można określać również mianem praw podmiotowych, traktując je jako prawa podmiotowe „względne”. Podstawą wyróżnienia takiej kategorii praw jest założenie,

\footnotetext{
${ }^{23}$ Szerzej zob. T. DĘBOwSKA-Romanowska, Dylematy interpretacyjne, s. 213-214n.

${ }^{24}$ Zob. art. 20, 21, 22, 6 Konstytucji RP.

${ }^{25}$ Zob. art. 47 Konstytucji RP.

${ }^{26}$ Zob. art. 32 Konstytucji RP.

${ }^{27}$ Zob. art. 2 Konstytucji RP.

${ }^{28}$ Zob. art. 7 Konstytucji RP.

${ }^{29}$ Zob. art. 86 ust. 1 w zw. z 88 ust. 3a pkt 4 lit. a) ustawy z dnia 11 marca 2004 r. o podatku od towarów i usług, tekst jedn.: Dz.U. z 2020 r., poz. 106 ze zm. [dalej: u.p.t.u.]; zob. wyrok TS UE z 23 kwietnia 2020 r., w sprawach połączonych C-13/18 i C-126/18; wyrok TK z 11 grudnia 2001 r. SK 16/00, Dz.U. z 2001 r., Nr 144, poz. 1621, oraz m.in.: wyroki NSA z 9 października 2014 r., I FSK 664/14, LEX nr 1587428; z 27 września 2016 r., I FSK 676/15, LEX nr 2142881; z 26 sierpnia 2016 r., I FSK 2011/14, LEX nr 2118529; z 3 czerwca 2016 r., I FSK 1865/15, LEX nr 2116884; a także wyrok WSA w Lublinie z 7 listopada 2017 r., I SA/Lu 574/17, LEX nr 242424. Zob. również A. BARTOSIEWICZ, VAT. Komentarz, LEX 2018 pkt 40.

${ }^{30}$ Zob. art. 72-77e ustawy z dnia 29 sierpnia 1997 r. ordynacja podatkowa, tekst jedn.: Dz.U. z 2020 r., poz. 1325 ze zm. [dalej: o.p.], a także J. GorĄCA-PACZULSKA, Komentarz do art. 78, [w:] Ordynacja podatkowa. Komentarz, red. H. Dzwonkowski, Warszawa: C.H. Beck 2020, s. 588-589; A. SZYMCZAK, Nadplata podatku powstała $w$ wyniku orzeczenia Trybunału Konstytucyjnego, „Ruch Prawniczy, Ekonomiczny i Socjologiczny” 75 (2013), nr 4, s. 107-118.
} 
że swoboda uznania administracyjnego w świetle norm prawa konstytucyjnego również ma swoje granice - warunkiem sine qua non ich identyfikacji jako praw podmiotowych podatnika jest ich bezpośrednie zakotwiczenie w prawach podstawowych unormowanych w Konstytucji RP oraz w Karcie Praw Podstawowych $\mathrm{UE}^{31}$. Wydaje się, że do tego rodzaju praw podmiotowych zaliczyć należy określane mianem preferencji podatkowych unormowane $\mathrm{w}$ ordynacji podatkowej ulgi $\mathrm{w}$ spłacie zobowiązań podatkowych ${ }^{32}$. Niestety, z uwagi na ograniczenia co do wielkości niniejszej publikacji tematyka dotycząca praw podmiotowych podatnika sensu largo jest w tym miejscu jedynie zasygnalizowana.

\section{PRAWA PODMIOTOWE PODATNIKA SENSU STRICTO UNORMOWANE W USTAWIE O PODATKU DOCHODOWYM OD OSÓB PRAWNYCH}

\subsection{Wybrane przykłady praw podmiotowych podatników podatku dochodowego od osób prawnych}

$\mathrm{Na}$ wstępie należy wskazać, że analiza obowiązujących przepisów u.p.d.o.p. pozwala na sformułowanie tezy, że prawodawca nie unika kodowania $\mathrm{w}$ przepisach tej ustawy praw podmiotowych. Kierując się omówionymi wyżej cechami wyróżniającymi prawa podmiotowe podatnika sensu stricto, w przekonaniu autorów, jako przykłady tego typu uprawnień przysługujących podatnikom można wskazać:

- prawo do wyboru „łącznego” opodatkowania spółek kapitałowych jako podatkowa grupa kapitałowa ${ }^{33}$;

- prawo do odliczania strat ${ }^{34}$

- prawo do wyboru roku podatkowego oraz prawo jego zmiany ${ }^{35}$;

- prawo do wyboru metody rozliczania różnic kursowych (metoda podatkowa lub metoda bilansowa $)^{36}$;

${ }^{31}$ Zob. Karta Praw Podstawowych Unii Europejskiej z dnia 7 czerwca 2016 r., Dz. Urz. UE C 202/389.

${ }^{32}$ Zob. art. 67a-67b o.p.

${ }^{33}$ Art. 1a ust. 1 u.p.d.o.p.

${ }^{34}$ Art. 7 ust. 5 u.p.d.o.p.

${ }^{35}$ Art. 8 u.p.d.o.p.

${ }^{36}$ Art. 9 b ust. 1 u.p.d.o.p. 
- prawo do dokonania korekty zysków przez podmioty powiązane ${ }^{37}$ oraz do celowego ukształtowania stosunku umownego z powiązanym kontrahentem tak, by móc skorzystać z tzw. bezpiecznej przystani (safe harbour) w zakresie usług o niskiej wartości dodanej oraz usług pożyczek ${ }^{38}$;

- prawo do ujmowania w przychodach podatkowych otrzymanych zaliczek, przedpłat, które podlegają zaewidencjonowaniu przy zastosowaniu kasy rejestrującej ${ }^{39}$;

- prawo do zastosowania dopuszczalnych zróżnicowanych zasad rozliczania przez podatników poniesionych kosztów prac rozwojowych ${ }^{40}$;

- prawo ustalenia przez strony umowy leasingu, która z nich będzie dokonywać amortyzacji przedmiotu leasingu ${ }^{41}$;

- prawo do skorzystania z następujących ulg podatkowych ${ }^{42}$ : ulga z tytułu dokonanej darowizny ${ }^{43}$, ulga na działalność badawczo-rozwojową ${ }^{44}$ oraz tzw. ulga na złe długi ${ }^{45}$.

Jako odrębny rodzaj uprawnień przysługujących podatnikowi, a spełniający warunki do kwalifikacji jako praw podmiotowych, można wskazać szereg rozwiązań z zakresu amortyzacji, np.:

a) prawo do ustalenia metody amortyzacji, wysokości stawek lub współczynników,

b) prawo do uznania za środek trwały składników majątkowych o wartości nieprzekraczającej 10 tys. zł,

c) prawo do jednorazowej amortyzacji nowych fabrycznie środków trwałych (do $100.000 \mathrm{zl})^{46}$.

Do wyłącznych uprawnień podatnika należy także:

- prawo wyboru przez małych podatników kwartalnych zaliczek ${ }^{47}$ oraz korzystania z jednorazowego odpisu amortyzacyjnego do $50.000 \mathrm{EUR}^{48}$;

\footnotetext{
${ }^{37}$ Art. 11e u.p.d.o.p.

${ }^{38}$ Art. 11 f oraz art. 11g u.p.d.o.p.

${ }^{39}$ Art. 12 ust. 3 g u.p.d.o.p.

${ }^{40}$ Art. 15 ust. 4 a u.p.d.o.p.

${ }^{41}$ Art. 17 f ust. 1 pkt 3 u.p.d.o.p.

${ }^{42} \mathrm{~W}$ tym uprawnieniu mieści się także prawo do określenia w ramach ustawowych limitów wysokości odliczenia z tytułu przysługujących ulg.

${ }^{43}$ Art. 18 u.p.d.o.p.

${ }^{44}$ Art. 18 d u.p.d.o.p.

${ }^{45}$ Art. $18 \mathrm{f}$ u.p.d.o.p.

${ }^{46}$ Art. 16k ust. 14 u.p.d.o.p.

${ }^{47}$ Art. 25 ust. 1 b u.p.d.o.p.

${ }^{48}$ Art. 16k ust. 7 u.p.d.o.p.
} 
- prawo podatników do wpłacania zaliczek uproszczonych ${ }^{49}$ oraz prawo podatników uzyskujących istotne przychody $\mathrm{z}$ działalności rolniczej do wpłacania zaliczek od dnia 20 października każdego roku ${ }^{50}$.

Odrębnego omówienia wymaga zakwalifikowanie do katalogu praw podmiotowych podatnika, prawa do uznania danego wydatku za podatkowy koszt uzyskania przychodów. Zgodnie z przepisami dochodem jest nadwyżka sumy przychodów nad kosztami ich uzyskania ${ }^{51}$. Zgodnie z treścią przepisów normujących definicję kosztów uzyskania przychodów, są nimi koszty poniesione w celu osiągnięcia przychodów ze źródła przychodów lub w celu zachowania albo zabezpieczenia źródła przychodów, z wyjątkiem kosztów wymienionych $\mathrm{w}$ art. 16 ust. 1 u.p.d.o.p. ${ }^{52} \mathrm{~W}$ powołanych przepisach nie zawarto sformułowania wskazującego na to, że podatnik „ma prawo” odliczyć koszty od przychodów. Wykładnia językowa prowadzi do jednoznacznej konkluzji, że przepisy te nie stwarzają podatnikowi alternatywnych rozwiązań. Nie stanowią one np., że „podatnik może...”, lub że „kosztami mogą być”, ale wyraźnie wskazują, co obiektywnie (ex definitione) za ten koszt się uznaje. W kolejnych zaś ustępach art. 15 u.p.d.o.p. prawodawca precyzuje, kiedy dany koszt „potrąca” się od przychodów.

Adresatem normy prawnej zawartej w analizowanych przepisach - oprócz podatnika podatku dochodowego - jest również organ podatkowy, który przepis ten stosuje w postępowaniu podatkowym, dokonując wymiaru podatku, wydając decyzję określającą wysokość podatkowego zobowiązania, podlegającą wykonaniu. Brzmienie przywołanego przepisu, nie uzależniając istnienia kosztu podatkowego od decyzji podatnika w tym względzie, chroni podatnika przed potencjalną próbą nieuzasadnionego zaprzeczania przez organ podatkowy istnieniu tych kosztów. Co więcej, dobrze poinformowany (!) organ podatkowy, rozstrzygając sprawę co do jej istoty (tj. wyliczając zobowiązanie podatkowe), nie może (!) pominąć tych korzystnych dla podatnika regulacji - $\mathrm{w}$ tym zakresie nie jest na to potrzebna zgoda, wniosek, oświadczenie woli podatnika. Pozytywna identyfikacja prawa podmiotowego nie zawsze bowiem musi być poprzedzona wyraźnym oświadczeniem woli podatnika (o czym będzie jeszcze dalej mowa). Jednocześnie na podkreślenie zasługuje to, że dobrze poinformowany organ podatkowy nie może wywodzić z pozytywnego skutku budżetowego, tj. względów fiskalnych

\footnotetext{
${ }^{49}$ Art. 25 ust. 6 u.p.d.o.p.

${ }^{50}$ Art. 25 ust. 1a u.p.d.o.p.

${ }^{51}$ Art. 7 ust. 2 u.p.d.o.p.

${ }^{52}$ Art. 15 ust. 1 u.p.d.o.p.
} 
(wyższego opodatkowania) uzasadnienia dla akceptacji stanu, w którym podatnik nie zaliczy danego wydatku do kosztów. Nieskorzystanie przez podatnika z określonych rozwiązań (niezaliczenie do kosztów) nie zwalnia organu $\mathrm{z}$ obowiązku uwzględnienia tych okoliczności w procesie wymiaru podatku. Skoro jest to obowiązek organu podatkowego wynikający z konstrukcji prawnej podatku, to podatnik teoretycznie nie powinien mieć prawa się temu sprzeciwić. A skoro tak, to - odnosząc się do aspektów definicyjnych praw podmiotowych - podatnik nie może z „tego prawa” nie skorzystać, będąc niejako „przymuszonym” przez organ do wykorzystania tego „prawa”, nawet wbrew swojej woli.

Taki sposób interpretacji wydaje się dopuszczalny z uwagi na publicznoprawny charakter podatków oraz jednostronność jego ustanawiania przez organy władzy ustawodawczej. Takie podejście oznaczałoby jednak, że we wskazanych przypadkach nie mamy do czynienia z prawami podmiotowymi. W praktyce jednak wydaje się, że względy fiskalne przesądzają o braku należytej motywacji organów podatkowych do kompleksowego uwzględniania całokształtu okoliczności, w których podatnik się znajduje (choć stoi to w sprzeczności z zasadą prawdy obiektywnej i zasadą zaufania, których to zasad organy winny bezwzględnie przestrzegać w ramach prowadzonego postępowania podatkowego), a przez to „narzucania” podatnikowi korzystnych dla niego rozwiązań. Z tego powodu koszty uzyskania przychodów oraz niektóre ulgi (odliczenie darowizn) mogą być uznawane za prawa podmiotowe przysługujące podatnikom, gdyż w sytuacji zasadnego uwzględnienia przez podatnika w rozliczeniu podatkowym tych elementów organ nie może odmówić ich zastosowania.

\subsection{Dodatkowe kryteria klasyfikacyjne}

W każdym z wymienionych rozwiązań prawnych decyzja podatnika co do wyboru określonego rozwiązania w żadnym momencie nie jest zależna od uznania administracyjnego organu podatkowego. Wybór dokonany przez podatnika jest jednocześnie wiążący dla organu podatkowego. Przedstawione powyżej przykłady nie wyczerpują katalogu konstrukcji prawnych, w których $\mathrm{w}$ naszej ocenie unormowane zostały prawa podmiotowe w ustawie o podatku dochodowym od osób prawnych. Niemniej jednak i ta relatywnie rozbudowana lista potwierdza, że podatkowe podmiotowe prawa są rozwiązaniem prawnym, po które polski prawodawca chętnie sięga na gruncie tego aktu prawnego. 
Podkreślenia wymaga, że nie są to jednak rozwiązania normatywne jednolite pod względem konstrukcyjnym. Co do zasady, w każdej z wyżej wymienionych sytuacji, w których zidentyfikowane zostały prawa podmiotowe, podatnik winien podjąć świadomą decyzję i wyrazić ją zgodnie z wymogami przewidzianymi przepisami prawa, najczęściej poprzez złożenie stosownego oświadczenia woli, określającego sposób i zakres korzystania z danego prawa. Oświadczenie to może mieć jednak w określonych przypadkach charakter dorozumiany (per facta concludentia), wynikający ze sposobu, w jaki podatnik postępuje, tj. wyłącznie na podstawie jego zachowania (jeżeli podatnik rozlicza różnice kursowe opierając się na metodzie podatkowej, to znaczy, że ją wybrał; jeżeli uiszcza zaliczki uproszczone, to znaczy, że je wybrał etc.). Obowiązek ujęcia przez podatnika tego rodzaju informacji w zeznaniu podatkowym nie warunkuje skuteczności dokonanego przez niego wyboru i ma jedynie charakter informacyjno-sprawozdawczy.

Za swoistego rodzaju źródło praw podmiotowych można również uznać sytuacje, w których celowe zaniechanie działania przez podatnika wywołuje określone (oczekiwane przez podatnika) skutki prawne. W niektórych sytuacjach niezłożenie przez podatnika wymaganego przez przepisy prawa oświadczenia może wiązać się np. z bardzo istotną zmianą jego sytuacji prawnopodatkowej. Jeżeli jest to działanie (zaniechanie) świadome, to wówczas podatnik ma możliwość faktycznego kreowania rzeczywistości podatkowej, „wybierając” jeden z wariantów opodatkowania (godząc się na takie a nie inne skutki podatkowe). Jako przykład można wskazać możliwość „wyboru” opodatkowania p.d.o.p. spółki jawnej (a raczej utraty prawa do utrzymania przez spółkę transparentności podatkowej na gruncie przepisów o podatkach dochodowych) - celowe niepoinformowanie organu podatkowego o składzie wspólników innych niż osoby fizyczne powoduje, że spółka jawna staje się podatnikiem tego podatku ${ }^{53}$. Choć racjonalność takiego działania może budzić poważne wątpliwości, to jednak obowiązujące przepisy pozwalają na sformułowanie wniosku, że obowiązek podatkowy może być również źródłem podatkowych praw podmiotowych (które można sklasyfikować jako „bierne” prawa podmiotowe) $)^{54}$. Z kolei sytuacje, w których skorzystanie przez podatnika $\mathrm{z}$ konkretnego prawa podmiotowego uzależnione jest od jego konkretnego działania (wyrażenia woli w drodze oświadczenia), kreują ,aktywne” prawa podmiotowe (np. prawo do opodatkowania ryczałtem od dochodów

\footnotetext{
${ }^{53}$ Art. 1 ust. 3 pkt 1a u.p.d.o.p.

${ }^{54}$ Art. 1 ust. 3 pkt 1a oraz art. 15 d ust. 1 pkt 2 w zw. z ust. 4 pkt 1 u.p.d.o.p.
} 
spółek kapitałowych uwarunkowane jest złożeniem do organu podatkowego stosownego zawiadomienia) ${ }^{55}$.

Analizując przedstawiony w poprzednim punkcie katalog przykładowych praw podmiotowych podatnika podatku dochodowego od osób prawnych, można również postawić pytanie, czy dla istnienia owego prawa jest wymagane, by generowało ono korzyści ekonomiczne dla podatnika? Oceniając ten dylemat, należy stwierdzić, że kwestia ta nie ma przesądzającego znaczenia dla istnienia prawa podmiotowego - istotą jest bowiem możliwość dokonania przez podatnika nieskrępowanego wyboru pomiędzy określonymi rozwiązaniami. To, co podatnik ostatecznie wybierze, nie musi być dla niego najkorzystniejsze - podatnik powołując się na określone prawa podmiotowe, może nieświadomie wybrać wariant dla siebie ekonomicznie nieopłacalny.

Katalog praw podmiotowych, z których podatnicy danego podatku mogą skorzystać, jest zróżnicowany w zależności do sytuacji prawnej podatnika. Bynajmniej nie oznacza to, że konstrukcja danego podatku jest niesprawiedliwa, gdyż w różny sposób traktuje podatników tego samego podatku. Wniosek taki wynika z faktu, że w odniesieniu do podatnika, który z określonego rozwiązania (prawa podmiotowego) skorzystał, zastosowanie znajdują odmienne regulacje prawne, będące konsekwencją podjętej przez niego decyzji o skorzystaniu z prawa podmiotowego (dokonanego wyboru).

Efektem procesu stanowienia prawa podatkowego jest określony standard opodatkowania. Z woli prawodawcy podatnik w określonych sytuacjach, o ile stosowne przepisy przewidują taką możliwość, może ewentualnie od tego standardu odstąpić, korzystając z przysługujących mu praw podmiotowych. Niepodjęcie przez podatnika żadnych działań w tym względzie (niepodjęcie decyzji co do zmiany tego stanu) powoduje, że realizowany jest określony (domyślny), wynikający z przepisów, scenariusz postępowania występują wówczas „standardowe” skutki podatkowe. Prawo podmiotowe (do bycia opodatkowanym na takich a nie innych zasadach) może się więc realizować zarówno poprzez świadomą akceptację przez podatnika stanu „domyślnego” (jeżeli w danym zakresie istnieje jeszcze jakieś inne „niestandardowe" rozwiązanie alternatywne, którego podatnik nie wybiera), rezygnację podatnika ze stanu domyślnego (,standardowego"), jak i w sytuacji

\footnotetext{
${ }^{55}$ Za kryterium klasyfikacyjne podatkowych praw podmiotowych na „,bierne” lub „aktywne” uznać należy konieczność podjęcia przez podatnika określonych działań (jakiejś aktywności), ażeby skorzystać z prawa (np. złożenie zawiadomienia, które warunkuje możliwość skorzystania $\mathrm{z}$ danego rozwiązania).
} 
odwrotnej - poprzez rezygnację z rozwiązania, które nie jest „standardem” i powrót do stanu „pierwotnego” („domyślnego”).

Takie spojrzenie na prawa podmiotowe umożliwia wyróżnienie podatkowych praw podmiotowych „standardowych” i „niestandardowych”. Za kryterium klasyfikacyjne podatkowych praw podmiotowych na "standardowe” lub „niestandardowe” uznać należy aktualną sytuację prawną podatnika. Jeżeli podatnik wybrał np. CIT estoński (skorzystał z prawa podmiotowego niestandardowego), ma prawo do tego, by z niego zrezygnować, czyli wybrać standard podatkowy.

Przykładowo - prawem podmiotowym „niestandardowym” będzie prawo wyboru przez spółki kapitałowe opodatkowania w formie podatkowej grupy kapitałowej ${ }^{56}$, czy też wybór bilansowej metody rozliczania różnic kursowych dla celów podatkowych ${ }^{57}$. „Standardem” jest bowiem odpowiednio: odrębne opodatkowanie spółek kapitałowych oraz metoda podatkowa rozliczania różnic kursowych. Spółka kapitałowa, jeżeli nie wchodzi w skład podatkowej grupy kapitałowej (PGK) i nie wybrała bilansowej metody rozliczania różnic kursowych, ma prawo oczekiwać, że organ podatkowy nie będzie traktował jej jako członka PGK i do celów rozliczania różnic kursowych nie będzie stosował przepisów z zakresu prawa bilansowego. W takiej sytuacji spółka realizuje „standardowe” prawa podmiotowe.

\section{WNIOSKI}

Uzasadnieniem zaproponowanej w niniejszym artykule systematyki praw podmiotowych podatników jest fakt, że u podstaw konstrukcji in generale praw podmiotowych leżą względy aksjologiczne wymykające się sztywnym regulacjom pozytywistycznym. Celem ich wprowadzania do treści norm podatkowych jest bowiem dążenie do zabezpieczenia realizacji podstawowych, odwiecznych ludzkich indywidualnych i społecznych potrzeb. Dlatego też prawodawca nie tworzy praw podmiotowych, ale jedynie je chroni i umożliwia realizację poprzez ich implementację $\mathrm{w}$ przepisach prawa przedmiotowego $^{58}$. O aksjologicznym charakterze publicznych praw podmiotowych podatnika świadczy - o czym już wspomniano - ich bezpośredni związek

\footnotetext{
${ }^{56}$ Zob. art. 1a u.p.d.o.p.

${ }^{57}$ Zob. art. 9 b ust. 3 u.p.d.o.p.

${ }^{58}$ Por. M. PyZIAK-SZAFniCKA, Prawo podmiotowe, „Studia Prawa Prywatnego” 1 (2006), z. 1, s. 51.
} 
z konstytucyjnymi wolnościami i prawa podatnika ${ }^{59}$. Mianownikiem łączącym wszystkie rodzaje praw podmiotowych podatnika zarówno tych unormowanych w Konstytucji, jak i w zwykłych ustawach podatkowych jest to, że $\mathrm{w}$ przypadku sporu podatników $\mathrm{z}$ organami podatkowymi podlegają one wyegzekwowaniu oraz ochronie sądowej przed sądami i trybunałami krajowymi i europejskimi ${ }^{60}$.

Zarówno konstytucyjne podmiotowe prawa podatnika, jak i przywołane przykłady praw podmiotowych unormowanych w u.p.d.o.p. wskazują na to, że na ten rodzaj uprawnień można spojrzeć jako na instrument, który może przyczynić się do zmiany modelu relacji uczestników stosunków podatkowoprawnych.

Wydaje się bowiem, że tradycyjny nierównorzędny stosunek łączący wyposażony we władztwo administracyjne organ podatkowy oraz zobowiązanego do uiszczania danin podatnika jest już coraz bardziej anachroniczny. $\mathrm{Z}$ dwóch naczelnych i połączonych ze sobą logicznie i merytorycznie funkcji podatkowych, czyli fiskalnej i redystrybucyjnej, wywieźć należy inny sposób postrzegania relacji na linii organ - podatnik. We współczesnych uwarunkowaniach gospodarczych i kulturowych każda ze stron stosunków podatkowoprawnych ma do spełnienia inne właściwe dla jej pozycji zadania i cele, a także obowiązki i uprawnienia.

Tak więc źródłem równorzędności czy też partnerstwa w relacjach pomiędzy organami podatkowymi a podatnikami jest ich wzajemna współpodległość. O tyle bowiem istnieje uzasadnienie dla istnienia organów władzy publicznej (w tym organów administracji podatkowej), o ile istnieją podmioty tym organom podporządkowane. Paradoksalnie „podporządkowanie” to ma charakter obustronny - organy władzy publicznej powołane są do służenia podmiotom, w odniesieniu do których władczymi uprawnieniami się legitymizują.

Powoływanie się podatników na przysługujące im prawa podmiotowe $\mathrm{w}$ toku stosowania prawa może zatem w znacznym stopniu przyczynić się do zbudowania, postulowanych od wielu lat w doktrynie, nowych form relacji/stosunków łączących organy podatkowe i podatników.

${ }^{59}$ T. BoJKowsKi, Wolności i prawa konstytucyjne podatnika, „Ruch Prawniczy, Ekonomiczny i Socjologiczny" 66 (2004), nr 3, s. 113.

${ }^{60}$ Por. tamże. 


\section{PIŚMIENNICTWO}

\section{Źródła prawa}

Konstytucja Rzeczypospolitej Polskiej z dnia 2 kwietnia 1997 r., Dz.U. Nr 78, poz. 483.

Ustawa z dnia 26 lipca 1991 r. o podatku dochodowym od osób fizycznych, tekst jedn.: Dz.U. z 2020 r., poz. 1426 ze zm.

Ustawa 15 lutego 1992 r. o podatku dochodowym od osób prawnych, tekst jedn.: Dz.U. z 2020 r., poz. 1406 ze zm.

Ustawa z dnia 29 sierpnia 1997 r. ordynacja podatkowa, tekst jedn.: Dz.U. z 2020 r., poz. 1325 ze zm.

Ustawa z dnia 11 marca 2004 r. o podatku od towarów i usług, tekst jedn.: Dz.U. z 2020 r., poz. 106 ze zm.

Karta Praw Podstawowych Unii Europejskiej z dnia 7 czerwca 2016 r., Dz. Urz. UE C 202/389.

\section{Literatura}

BABIARz Stefan: Majątkowe i niemajątkowe prawa i obowiazki w systemie praw, cz. II. Majątkowe i niemajątkowe prawa i obowiazki w prawie podatkowym. Teza $\mathrm{nr}$ 1, „Zeszyty Naukowe Sądownictwa Administracyjnego" 2006, nr 2, s. 21-40.

BRZEZIŃSKI Bogumił: Koncepcja praw podatnika i ich ochrony jako przedmiot badań naukowych, „Kwartalnik Prawa Podatkowego” 2005, nr 1, s. 9-34.

BrZezińsKi Bogumił: Deklaracja Praw Podatnika (propozycja systematyzacji tez), „Kwartalnik Prawa Podatkowego" 2008, nr 2, s. 111-121.

BRZEZIŃSKI Bogumił, FRANCZAK Agnieszka: Wymiana informacji podatkowych a ochrona praw podstawowych $w$ sferze opodatkowania - wyrok TSUE w sprawie Berlioz (C-682/15) Glosa, „Problemy Współczesnego Prawa Międzynarodowego, Europejskiego i Porównawczego" 17 (2019), s. 269-278.

BoJKOwSKI Tomasz: Wolności i prawa konstytucyjne podatnika, „Ruch Prawniczy, Ekonomiczny i Socjologiczny" 66(2004), nr 3, s. 113-126.

Chauvin Tatiana, Stawecki Tomasz, Winczorek Piotr: Wstęp do prawoznawstwa, Warszawa: C.H. Beck 2013.

DęBowska-Romanowska Teresa: Dylematy interpretacyjne artykułu 217 Konstytucji, [w:] Ex iniuria non oritur ius. Księga ku czci Profesora Wojciecha Łączkowskiego, red. A. Gomułowicz, J. Małecki, Poznań: Wydawnictwo Printer 2003, s. 207-229.

Duniewska Zofia, JAworska-DęBSKa Barbara, Stahl Małgorzata [i in.], Prawo administracyjne. Pojęcia, instytucje, zasady w teorii i orzecznictwie, Warszawa: Wolters Kluwer 2009.

DzwonkowsKi Henryk, DudA Mikołaj, Gorąca Jolanta: Zakres i treść istniejącej i pożądanej ochrony praw podatnika (ustalenia de lege lata i postulaty de lege ferenda), http://orka.sejm. gov.pl/wydbas.nsf/0/A045899E99633E82C1257FB200456DB9/\$File/Strony\%20odDylematy \%20reformy\%20systemu\%20podatkowego-12.pdf [dostęp: 8.07.2020].

Etel Leonard, Babiarz Stefan, DowgIer Rafał [i in.], Nowa Ordynacja Podatkowa. Z prac Komisji Kodyfikacyjnej Ogólnego Prawa Podatkowego, Białystok: Temida 22017. 
FrANCZAK Agnieszka: Standardy ochrony praw podatnika w Karcie Praw Podstawowych $i$ ich stosowanie w orzecznictwie sądów administracyjnych, ,Roczniki Nauk Prawnych” 30 (2020), nr 1, s. 33-48.

GOMUŁOWICZ Andrzej: Ochrona wolności i praw ekonomicznych a granice opodatkowania - zasady i kontrowersje, „Ruch Prawniczy, Ekonomiczny i Socjologiczny” 67 (2005), nr 3, s. 19-33.

GorAcA-PACZUlSKA Jolanta: Komentarz do art. 78, [w:] Ordynacja podatkowa. Komentarz, red. H. Dzwonkowski, Warszawa: C.H. Beck 2020, s. 588-589.

JAKIMOWICZ Wojciech: Publiczne prawa podmiotowe, Kraków: Wolters Kluwer 2002.

KACZOR Jacek: Nadużycie prawa podmiotowego, [w:] Z zagadnień teorii i filozofii prawa. Autonomia prawa ze stanowiska teorii i filozofii prawa, red. J. Helios, Wrocław: Wydawnictwo Uniwersytetu Wrocławskiego 2003, s. 111-129.

KASZNICA Stanisław: Polskie prawo administracyjne, Poznań: Księgarnia Akademicka 1946.

KISZKA Joanna: Zasady ochrony podatnika $w$ orzecznictwie Europejskiego Trybunatu Sprawiedliwości, „Gdańskie Studia Prawnicze” 16 (2007), nr 1, s. 455-483.

KrZYwoń Adam: Podatki i inne daniny publiczne w Konstytucji Rzeczypospolitej Polskiej, Warszawa: Wydawnictwo Sejmowe 2011.

Münnich Monika: Deklaracja Praw Podatnika, [w:] Preferencje podatkowe, red. B. Kucia-Guściora, M. Burzec, Lublin: Wydawnictwo KUL 2013, s. 13-28.

NAPIÓRKOWSKa Anna: Czy ktoś chroni podatnika?, [w:] Podatnik versus organ podatkowy, red. P. Borszowski, A. Huchla, E. Rutkowska-Tomaszewska, s. 146-147, https://www.biblioteka cyfrowa.pl/dlibra/publication/37394/edition/38915/content [dostęp: 5.07.2021].

PyziaK-SzAFNiCKa Małgorzata: Prawo podmiotowe, „Studia Prawa Prywatnego” 1 (2006), z. 1, s. 41-127.

TOMASZEWSKA Katarzyna: Znaczenie i zakres ochrony publicznych praw podmiotowych a ochrona interesu jednostki, s. 113-134, http://www.bibliotekacyfrowa.pl/Content/39984/06_Katarzyna_ Tomaszewska.pdf [dostęp: 11.09.2020].

TUlEJA Piotr: Stosowanie Konstytucji RP w świetle zasady jej nadrzędności (wybrane zagadnienia), Kraków: Zakamycze 2003.

S巨̨K Małgorzata: Karta Praw Podatnika w polskim systemie podatkowym w świetle doświadczeń zagranicznych, „Kwartalnik Prawa Podatkowego” 2018, nr 1, s. 71-96.

SzCZUReK Bożena: Koncepcja ochrony praw podatnika. Geneza, rozwój, perspektywy, Warszawa: C.H. Beck 2008.

SZYMCZAK Aneta: Nadplata podatku powstała $w$ wyniku orzeczenia Trybunatu Konstytucyjnego, „Ruch Prawniczy, Ekonomiczny i Socjologiczny” 75 (2013), nr 4, s. 107-118.

WILK Michał: Potrzeba wprowadzenia Karty Praw Podatnika w Polsce, „Kwartalnik Prawa Podatkowego" 2018, nr 1, s. 97-104.

WronKowSKA Sławomira: Sytuacje wyznaczone przez normy prawne, [w:] Andrzej ReDELBACH, Sławomira WronkowsKA, Zygmunt ZIEMBIŃSKI, Zarys teorii państwa i prawa, Warszawa: PWN 1994. 


\section{WEZZŁOWE PROBLEMY \\ DOTYCZĄCE PRAW PODMIOTOWYCH PODATNIKÓW}

\section{Streszczenie}

Przedstawiciele polskiej doktryny podatkowej koncentrują się w swych rozważaniach z reguły na ogólnych prawach podatnika oraz ich ochronie, natomiast nie jest szerzej podejmowana problematyka dotycząca publicznych praw podmiotowych podatnika. Lukę tę wypełnia niniejszy artykuł, którego celem jest, po pierwsze, teoretyczna analiza pojęcia prawa podmiotowego. Po wtóre, próba usystematyzowania unormowanych w różnych aktach prawnych przysługujących podatnikom praw podmiotowych. Po trzecie, ukazanie na podstawie egzemplifikacji wybranych praw podmiotowych unormowanych w podatku dochodowym od osób prawnych ich potencjalnego znaczenia jako instrumentów zabezpieczających prawa podatnika i podstawę do kształtowania nowych relacji pomiędzy nimi a organami podatkowymi opartych na partnerstwie i równorzędności.

Słowa kluczowe: prawo podmiotowe; prawa podatnika; podatek dochodowy od osób prawnych; organy podatkowe 